\title{
Research on RMS Data Analysis and System Construction of Digitized Forces
}

\author{
Haiqing Wang ${ }^{1, a}$, Ping $\mathrm{Gu}^{1, \text { a }}$, Zengguang Wang ${ }^{1, \text { a and Wei Zhang }}{ }^{\text {2,a }}$ \\ ${ }^{1}$ Equipment Command and Management Department, Mechanical Engineering College, \\ Shijiazhuang, China \\ ${ }^{2}$ Huailai ordnance equipment warehouse, Zhangjiakou, China \\ awang1223797579@163.com
}

Keywords: Digitized forces, RMS, data collection.

\begin{abstract}
The collection of Reliability, maintenance and supportability (RMS) data is the important basis for preparing to construct and deploy equipment support system and its support resource. It has an important significance for the construction of digital troops. This paper begins with the analysis of the characteristics of digital military equipment, followed by the study of the RMS parameters of typical digital equipment and then the RMS data system of military equipment was constructed. The research of this paper may establish foundation for planning and designing equipment support system and its support resource, and have very important realistic meaning and significant military value for raising the equipment support ability of digitized forces and accelerating digitized equipment forming combat effectiveness.
\end{abstract}

\section{Introduction}

Digital force is a new type of troops, which plays an important role in the future war. AS an important part of the construction of digital troops, equipment support system and its security resources are important to maintain and restore the equipment performance, and play an important role in the combat effectiveness of weapons and equipment[1]. Equipment support system and its own security resource planning and design can not be separated from the data acquisition and analysis of the digital equipment reliability, maintainability and security (RMS). RMS data acquisition and analysis is an important basis for the establishment and configuration of equipment support system and its security resources.

Compared with the western developed countries, our army equipment in the delivery of troops, due to the lack of data acquisition and analysis of RMS and the corresponding support system. It is difficult to solve problems making for the maintenance of equipment of the new force, resulting in delays in the new equipment form a protective barrier ability and fighting capacity.

It is necessary to collect and analyze the RMS data of the whole element equipment of the digital troops in order to make the weapons and equipment of the digital troops in a timely and reasonable to carry out maintenance analysis and planning and then ensure weapons and equipment capable of playing their due combat effectiveness[2]. Therefore, this paper begins with the analysis of the characteristics of digital military equipment, followed by the study of the RMS parameters of typical digital equipment and then the RMS data system of military equipment was constructed. The research of this paper may establish foundation for planning and designing equipment support system and its support resource.

\section{THE BASIC THEORY OF KNOWLEDGE}

\subsection{The Main Features of Digital Equipment}

Along with tentacles of military information technology into every field of national defense military weaponry, weaponry development will continue to be a direction of systematization and modularization and will gradually achieve information digitalization, accurate and remote, armed 
with a light-duty and stealth. Digital weapons will achieve the cross time jump, so that the equipment new stage from mechanization to the information, and presents some new characteristics[3].

(1) The core performance of weapons and equipment has a new breakthrough.

(2) The operational effectiveness of weapon equipment can be in greatly improved.

(3) The informatization degree of weapon equipment is higher and higher.

(4) Weapons and equipment has a dual function of combat and protection.

(5) The integration trend of weapon equipment is becoming more and more obvious.

\subsection{Requirement Analysis Process of RMS Parameters for Typical Digital Equipment}

In view of the particularity of the digital equipment, the traditional RMS parameter description can not be fully applicable, so the build of the RMS data system for new digital equipment is necessary. In the construction, the RMS parameters is selected which can describe the characteristics of the digital equipment system. The selection of RMS parameters is according to the main factors of the impact forces equipment support resource allocation and optimization in order to determine RMS parameters directly related to the configuration and optimization of equipment support resources[4]. And then, the system data of RMS is determined according to the equation of RMS parameter. The detail procedure is shown in figure 1.

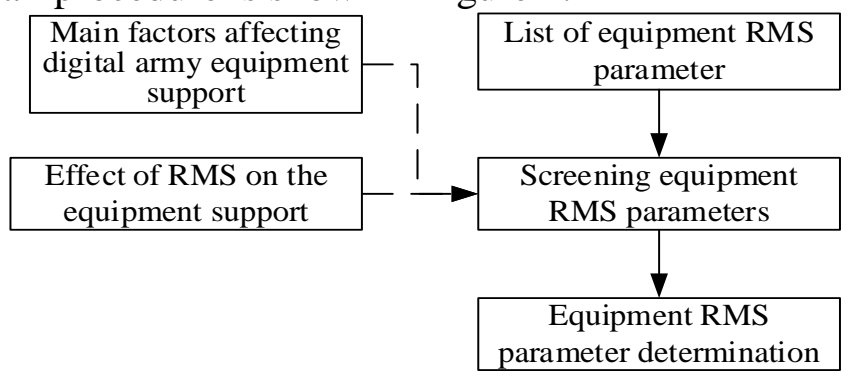

Figure 1 Analysis process of RMS parameter requirements

\section{THE RMS PARAMETERS OF TYPICAL DIGITAL EQUIPMENT}

The equipment digital RMS parameters can be divided into RMS comprehensive parameter, RMS single parameter and the guarantee system and its resource parameters according to the main factors of digitization army equipment support resource allocation and optimization and the influence of RMS on the equipment support resource allocation and optimization[5]. This paper focuses on the comprehensive RMS parameters. Different equipment can choose different comprehensive parameters. The commonly used comprehensive parameters can be divided into the combat readiness parameters, the success of the mission parameters and deployment parameters.

\subsection{The Combat Readiness Parameters}

(1) Operational Availability $\left(A_{0}\right)$

Availability is one of the available parameters that can be related to the working time and can be expressed as the ration of the working time and total time. Its formula is shown in formula 1 .

$A_{0}=\frac{T_{U}}{T_{T}}=\frac{T_{U}}{T_{U}+T_{D W}}=\frac{T_{O}+T_{S}}{T_{O}+T_{S}+T_{C M}+T_{P M}+T_{O S}+T_{D}}$

In the formula, $T_{U}$ indicates the time to work, $T_{T}$ represents the total available time, $T_{D W}$ represents inoperable time, $T_{O}$ represents working time, $T_{S}$ represents spare standby time, $T_{C M}$ represents the total corrective maintenance time, $T_{P M}$ represents the total time of preventive maintenance, $T_{O S}$ represents the use of security time, $T_{D}$ represents the delay time, $A_{0}$ is a parameter that is generally used in the initial stage of use or the subsequent use of the evaluation phase.

(2) Utilization ratio $\left(R_{U}\right)$ 
The utilization ratio is one of the parameters that are required to be used in operation[6]. It is the ratio of the actual working hours in the calendar time. $R_{U}$ is a parameter related to the readiness of equipment and the use of policy relevant. Its formula is shown in formula 2.

$$
R_{U}=\frac{T_{0}}{T_{T}}
$$

(3) Rate of tasks can be performed ( $\left.R_{M C}\right)$

Rate of tasks can be performed represents the equipment can carry out a task within the specified time which has a ratio of the total time period. It is the use of parameters, general assessment in service stage. Its formula is shown in formula 3.

$$
R_{M C}=\frac{T_{M C}}{T_{T}}=\frac{T_{F M C}+T_{P M C}}{T_{T}}
$$

In the formula, $T_{M C}$ represents at least the time to perform a task, $T_{T}$ represents the total available time, $T_{F M C}$ represents it can perform all of the tasks, $T_{P M C}$ represents it can perform some of the tasks.

(4) Preparation time before the task $\left(T_{S T M}\right)$

Preparation time before the task is the time to prepare the equipment into the state capable of performing the required tasks. In other word, it is time operational status of forces before the battle usually required by the state to combat readiness (Sometimes forces can also be in stages).

(5) Preparation time out again $\left(T_{T A}\right)$

The mission of continuous equipment needs from the end of the last task to start out again required to perform a task preparation time which can be synthetic single index of finer. This parameter can be used as a parameter, also can make the contract parameters.

\subsection{The Success of the Mission Parameters}

There are many factors influencing the completion of a task, such as the battlefield environment condition and equipment features, etc. Common mission success parameters is the degree of mission success $D$.It takes into account the probability to finish the task from the perspective of reliability and maintainability design characteristics, represented by the following tasks reliability and degree of damage and repair tasks. $D$ is a use of parameters, the conditions can be defined as a contract parameter. Its formula is shown in formula 4.

$$
D=R_{M}+\left(1-R_{M}\right) M_{M}
$$

In the formula, $R_{M}$ represents the reliability of the task, generally equipped with a complete mission profile indicates reliability. If the maintenance (repair) is not allowed in the case of the task $D=R_{M} . M_{M}$ represents the maintenance task, generally used in the mission profile of maintenance in the maintenance level and the prescribed period of time (repair) demaged equipment so that it can continue to fight probability.

\subsection{Deployment Parameters}

Deployment parameters are generally used to deploy a combat unit to represent the traffic. It is equipped with a system including the deployment of combat units and support resources (including equipment) the transport volume. The parameters evaluated in using stage.

\section{RMS data system of military equipment}

According to the previous analysis, this paper analyzed the RMS parameters of the equipment and constructed the RMS data system, which mainly analyzed the comprehensive parameters. The RMS parameters system of typical digital equipment is constructed taking the comprehensive parameters as the main research content. The content of parameter system is shown in table 1 . The 
RMS parameters system of typical digital equipment mainly includes parameter types, parameter names, data names, verification and timing verification method.

Table 1 Military equipment RMS integrated data

\begin{tabular}{|c|c|c|c|c|}
\hline Parameter type & $\begin{array}{l}\text { Parameter } \\
\text { name }\end{array}$ & Data name & $\begin{array}{c}\text { Timing } \\
\text { verification }\end{array}$ & $\begin{array}{c}\text { Verification } \\
\text { method }\end{array}$ \\
\hline \multirow{17}{*}{$\begin{array}{c}\text { Combat } \\
\text { Readiness } \\
\text { Parameters }\end{array}$} & \multirow{6}{*}{$\begin{array}{l}\text { Operational } \\
\text { Availability }\end{array}$} & Operating hours & \multirow{6}{*}{$\begin{array}{l}\text { Production } \\
\text { seeting } \\
\text { Use phase }\end{array}$} & \multirow{6}{*}{$\begin{array}{l}\text { Experimental } \\
\text { Verification } \\
\text { Use assessment }\end{array}$} \\
\hline & & Standby time & & \\
\hline & & total corrective maintenance time & & \\
\hline & & total preventive maintenance time & & \\
\hline & & use of security time & & \\
\hline & & delay time & & \\
\hline & \multirow{2}{*}{$\begin{array}{l}\text { Utilization } \\
\text { ratio }\end{array}$} & Operation time & \multirow{2}{*}{ Use phase } & \multirow{2}{*}{ Use assessment } \\
\hline & & total available time & & \\
\hline & \multirow{3}{*}{$\begin{array}{l}\text { Rate of tasks } \\
\text { can be } \\
\text { performed }\end{array}$} & Time to perform all tasks & \multirow{3}{*}{ Use phase } & \multirow{3}{*}{ Use assessment } \\
\hline & & Time to perform some task & & \\
\hline & & total available time & & \\
\hline & \multirow{3}{*}{$\begin{array}{l}\text { Preparation } \\
\text { time before } \\
\text { the task }\end{array}$} & Preparatory work before task & \multirow{3}{*}{$\begin{array}{c}\text { Design } \\
\text { stereotype } \\
\text { Use phase }\end{array}$} & \multirow{3}{*}{$\begin{array}{l}\text { Demonstration } \\
\text { experiment } \\
\text { Use assessment }\end{array}$} \\
\hline & & $\begin{array}{c}\text { Manpower requirements and tools } \\
\text { limits for each jib }\end{array}$ & & \\
\hline & & Timing of the work & & \\
\hline & \multirow{3}{*}{$\begin{array}{l}\text { Preparation } \\
\text { time out } \\
\text { again }\end{array}$} & Preparatory work before task & \multirow{3}{*}{$\begin{array}{l}\text { Design } \\
\text { stereotype } \\
\text { Use phase }\end{array}$} & \multirow{3}{*}{$\begin{array}{l}\text { Experimental } \\
\text { Verification } \\
\text { Use assessment }\end{array}$} \\
\hline & & $\begin{array}{l}\text { Manpower requirements and tools } \\
\text { limits for each jib }\end{array}$ & & \\
\hline & & Timing of the work & & \\
\hline \multirow{2}{*}{$\begin{array}{l}\text { Success of } \\
\text { Mission } \\
\text { Parameters }\end{array}$} & \multirow{2}{*}{$\begin{array}{l}\text { Task } \\
\text { completion }\end{array}$} & Task reliability & \multirow{2}{*}{$\begin{array}{l}\text { Design } \\
\text { stereotype }\end{array}$} & \multirow{2}{*}{$\begin{array}{l}\text { Experimental } \\
\text { Verification }\end{array}$} \\
\hline & & Task maintenance degree & & \\
\hline \multirow[b]{2}{*}{$\begin{array}{l}\text { Deployment } \\
\text { parameter }\end{array}$} & \multirow{2}{*}{$\begin{array}{c}\text { Transport } \\
\text { volume of } \\
\text { operational } \\
\text { units } \\
\end{array}$} & Types of transport & \multirow[b]{2}{*}{$\begin{array}{l}\text { Using } \\
\text { parameters }\end{array}$} & \multirow[b]{2}{*}{ Use evaluation } \\
\hline & & Number of transport vehicles & & \\
\hline
\end{tabular}

\section{Conclusion}

Reliability, maintainability and supportability parameter index system is the basis for the security of force and combat effectiveness of the digital equipment, which reflects the requirement of military equipment to ensure combat tactics[7]. In this paper, the analysis process of RMS parameter of typical digital equipment is proposed on the basis of the characteristics of typical digital equipment. Taking the comprehensive guarantee parameter as an example, the RMS parameters of typical digital equipment are defined and the RMS parameter system is constructed, which is of guiding significance for the selection of RMS parameters of digital troops. The research has very important practical significance and military value to improve the capability of digital troops and speed up the formation of the digital equipment.

\section{References}

[1] Li Shi-ying, QU Chang-zheng, XUE Wen-li. Study on the RMS Parameters System Framework of Informationization Equipment System [J].Journal of Academy of Armored Force Engineering, 2008, 22(6):39-42.

[2] LI Shi-ying, YU Yong-li, LI Dong-dong, QU Chang-zheng. Influence analysis of RMS of Informationization Equipment on Its Mission Effectiveness [J].Machinery Design \& Manufacture, 2009(7): 228-230. 
[3] Xu Jie. Reliability, Maintainability and Survivability of the Weapon Equipment [J]. Marine Electric, 2012,32(3):45-46.

[4] Ding Ding-hao, LU Jun.Discussion on the System of Reliability, Maintainability and Supportability Parameters[J]. Journal of CAEIT,2011, 6 (2) :170-174.

[5] XUE Lu-qiang,SHAN Yue-chun,SUI Jiang-bo. Research on influence of Ship-to-air Missile System's reliability and Maintainability to Training efficiency $[\mathrm{J}]$. Command Control \& Simulation,2011.33(6):106-108.

[6] CHEN Yan-qiao, WEI Shu-hua, JIN Jia-shan. Collecting and analyzing system of warship electrical equipment reliability information[J]. Journal of Computer Applications, 2012, 32(S2): 273-275.

[7] TIAN Li-dong. Reliability, Maintainability and Supportability of Ruggedized External Equipment[J].Effcifonic Product Reliability and Environment Testing,2011,30(5):78-134. 